\title{
TTR
}

Traduction, terminologie, rédaction

\section{Kathryn Batchelor. Translation and Paratexts. London/New York, Routledge, 2018, 202 p.}

\section{Şehnaz Tahir Gürçağlar}

Volume 31, numéro 2, 2e semestre 2018

URI : https://id.erudit.org/iderudit/1065575ar

DOI : https://doi.org/10.7202/1065575ar

Aller au sommaire du numéro

\section{Éditeur(s)}

Association canadienne de traductologie

\section{ISSN}

0835-8443 (imprimé)

1708-2188 (numérique)

Découvrir la revue

Citer ce compte rendu

Tahir Gürçağlar, Ş. (2018). Compte rendu de [Kathryn Batchelor. Translation and Paratexts. London/New York, Routledge, 2018, 202 p.] TTR, 31(2), 219-224. https://doi.org/10.7202/1065575ar d'utilisation que vous pouvez consulter en ligne.

https://apropos.erudit.org/fr/usagers/politique-dutilisation/ 


\section{COMPTES RENDUS}

\section{Kathryn Batchelor. Translation and Paratexts. London/New York, Routledge, 2018, 202 p.}

The concept of "paratext" as put forth by Gérard Genette in Seuils (1987), published as Paratexts in English translation in 1997, has opened up a fertile area for translation research since the 1990s, starting with seminal studies by Theo Hermans (1996) and Urpo Kovala (1996). The soaring interest in the concept has brought forth myriad case studies, mainly in literary translation, that focus on the various paratextual elements surrounding translations, particularly on the peritexts. In the meantime, the rich cultural and temporal range of the case studies has not resulted in an extensive theoretical questioning of the concept and its heuristic capacity for translation research. This is precisely the gap Kathryn Batchelor addresses in her new book, where she explores the issue of paratexts from within an interdisciplinary framework. Translation and Paratexts is a long overdue work on the insights brought by paratexts to translation studies, as well as the neighbouring disciplines of digital and media studies, and is essential reading for the many researchers already convinced that translation analysis can never be complete without incorporating those visible and invisible elements surrounding translations into their investigations of texts. The book is written in three interconnected parts, each comprising several chapters.

Part I offers an overview of Genette's notion of the paratext and its adoption by translation studies, as well as by digital, media and communication scholars. This part is both critical and informative, and researchers and graduate students preparing to work hands-on with paratexts will find it useful, and benefit from its interdisciplinary insights.

Part II contains three case studies; the first one, in Chapter 4, explores the relevance of the notion of "authorized translation" for paratexts via English versions of Nietzsche. Chapter 5, co-authored with Sarah Fang Tang, who selected and mediated the corpus for Batchelor, includes the second case study, on Chinese paratexts of Western translation theory texts published in China. The third case study, in Chapter 6, goes into the realm of media studies and audiovisual translation, and is about a British show presenting foreign drama to British viewers. Although each is full of interesting 
insights, the case studies offered in Part II do not organically follow or foreshadow the discussions in Part I and Part III; there is considerable disconnect between their case-specific findings, and the larger theoretical and methodological conclusions in the final part of the book. However, this does not reduce their value, since each case study features diligently researched and carefully analysed data, and is a prime example of empirical research in translation.

Part III focuses on theoretical questions pertaining to paratextuality in translation studies. Chapter 7 includes a careful terminological and typological delineation of Batchelor's notion of the paratext, while Chapter 8 offers a number of research topics and methodologies that can be tapped into via paratextual perspectives. Part III is very much the heart of the book; it is the part where Batchelor offers her original contributions to the theory of the paratext, while also presenting some sound research advice and innovative research ideas that incorporate paratexts.

\section{Questions of definition}

Kathryn Batchelor opens her study with a quote from Genette who wrote: "Paratextuality [...] is first and foremost a treasure trove of questions without answers" (1997a, p. 4, in Batchelor, p. 1). Throughout its various sections, the book proves Genette right, and Batchelor ends up posing more questions than answering them. This is not to say that she does not clarify aspects of Genette's paratextuality that have been glossed over or simply ignored in previous research. On the contrary, the author opens up various elements of the paratext to rigorous scrutiny, and is able to draw a relatable and workable boundary around the concept. In fact, most of the work focuses on questions to determine what a paratext really is and what it potentially needs to be in the context of translation research. It is clear that as elements guiding the reception of texts, both the materiality and the function of paratexts need to be taken into consideration (p.10). While the structure of Seuils encourages an emphasis on the materiality of the paratext, Batchelor opens up a discussion on the functions of the paratext centering around the question of authorial intention (pp.12-17). She posits that Genette builds a special connection between the paratext and authorial intention (p.13), and convincingly argues that this has been overlooked by translation researchers. According to the author, with the exception of a few researchers (such as Sharon Deane-Cox, 
2014 and Şehnaz Tahir Gürçağlar, 2002), translation scholars have adopted a pragmatic approach, while integrating the paratext into their interpretive efforts and "tak[ing] those aspects [...] which can be readily adapted to the discipline without any theoretical maneuvering" (p. 28). As she critiques the existing literature, Batchelor goes beyond the typical meaning ascribed to paratexts in translation studies that limits the concept effectively to Genette's peritext (p. 27). The author supports a careful expansion of the realm of the paratext in the context of translation and argues that "to try to define the paratext is always to negotiate around its blurry borders, both inward facing (towards the text) and outward-facing (towards the broader context" (p. 17). While Batchelor echoes Genette's concern about the methodological consequences of an over-expansion of the paratext's boundaries, she finds Genette's solution to such expansion problematic. Genette recommends that the paratext's function be kept consistent with the author's purpose (Genette, 1997b, p. 407 and Batchelor, p. 17). For Batchelor, the decoupling of the paratext's function from authorial intention is key in ensuring a fruitful adaptation of the concept to translation studies.

Batchelor offers her own definition of the paratext for use within translation studies and it is one which associates it with another term that Genette himself has used, namely "threshold," i.e. "seuils." In her definition, "[a] paratext is a consciously crafted threshold for a text which has the potential to influence the way(s) in which the text is received" (p.142). This definition bypasses the need to situate the paratext in physical contact with the text, since the term "threshold" is used both as a material and figurative concept; Batchelor's paratexts go beyond those surrounding literary texts and are also thresholds to digital and media texts, even including such spaces as an interpreter's body in the case of interpreter mediated interactions. The phrase "consciously crafted" in the definition avoids an over-expansion of the borders of paratexts and their blending into the larger context (p. 143). The undeniable strength of the definition is the way it enables a discussion from the perspectives of both the producer and the receiver (ibid.) and liberates the paratext from the yoke of authorial intention.

The lack of a theorization on the paratext in translation studies also reveals a general indifference to Genette's approach to translation as paratext. Genette has been criticized by translation scholars for his approach mainly because it upholds the traditional hier- 
archies between translator and author, and translation and source text. Batchelor, by contrast, invites a closer look at the potentialities of studying translations as paratexts. She stresses the variability of the paratext in Genette's framework that helps a text to adapt to new environments and concerns, notwithstanding Genette's insistence on anchoring the paratext in authorial intention (p. 29). Another potential interest in considering translation as paratext lies in the field of translation as literary criticism, i.e. a "mode of intense or critical reading" that Batchelor returns to in Part III (p. 185).

\section{Terminology, typology and potential research}

The last chapter of Part I in Translation and Paratexts delves into how scholars in digital and media studies have managed to overcome some of the limitations and constraints posed by Genette's perspective on paratexts, and have used the notion as a fruitful heuristic tool. Batchelor returns to the findings of this chapter in her case studies, and particularly in the last part, where she offers a broader, functionally-oriented (rather than material) and methodologically flexible notion of the paratext. In Chapter 7, she explores the semantic features of the term "paratext," and contrasts them with a range of different terms, namely "framing," "extratext," "metatext," "metadiscourse" and "paratranslation." Her preference is for retaining the term "paratext" since this would provide the possibility of incorporating one's research into an existing theoretical tradition, not only in literary studies, but also in translation, digital and media studies. The same chapter includes suggestions for expanding the typology of paratexts created by Genette to better suit the needs of translation research. What truly stands out is a possible direction of research on absent paratexts, i.e. how paratexts are specifically excluded from the translation of certain texts (p. 161).

Batchelor offers a general summary of themes in paratextrelated translation research in Part I. In Part III, she explores the potential of paratexts for future research in a rather "eclectic" vein, as she herself affirms. She starts Chapter 8 by discussing the inherent benefits of considering paratexts in product-oriented research with the study of paratextual conventions and the study of paratexts as documents, which comes with a series of methodological questions on reliability. In this section, Batchelor also deals with the analysis of images and multimodal texts in relation to paratexts and offers a specific visual grammar for the exploration of such issues. This is 
followed by the potential of a paratextual perspective for processoriented research, where Batchelor suggests that paratexts may have a place in cognitive process research in translation. After a foray into interpreting studies, which I return to in the next paragraph, Batchelor closes the chapter with a fruitful discussion on how translations, when regarded as paratexts to literature, may deepen our appreciation of literary works, by studying translations "alongside originals" rather than "in place of originals" (p. 188).

One of the author's most innovative contributions comes from her positioning of the interpreter as a paratext. The expansion of the definition of the paratext beyond that of the peritext and epitext opens up new avenues where the encounter between the receiver and the text can be conceptualized in much broader terms, and carries it outside the borders of written texts. One extension of this idea is that paratextual research may also be used in interpreting studies where the interpreters themselves become thresholds that are "consciously crafted" (p. 142) since "they might shape the listener's understanding of the text" in conference or dialogue interpreting (p. 180). Batchelor refers to three types of paratextual devices that may be used by interpreters at any given time: prosodic, linguistic and corporeal. She hopes that this perspective will help further problematize the position of the interpreter as a neutral and invisible "machine," and may draw attention to certain interpreting settings, such as adhoc interpreting, where the interpreter's mediating role is more salient. However, she ends her discussion by arguing that the concept of the interpreter as "threshold" in dialogue interpreting is problematic, since the parties are all present in the same setting and have direct access to each other's verbal and non-verbal cues; therefore, social interaction-focused models may be a better fit for studying dialogue interpreting. Batchelor argues that the concept of the paratext will be more productive for studying monologic forms of interpreting, such as conference interpreting (p.185). Unfortunately, she does not engage in an extensive discussion on this issue, as she does with dialogue interpreting, and her references are limited to one study. This is indeed a very interesting discussion, although further inquiry into the subjectivity and agency of the interpreter is needed before one can comfortably adopt the interpreter as a "paratext" in a research framework. Can agency be equated with the linguistic utterance, prosody or corporeal conduct of the interpreter? What is the role and position of the interpreter apart from serving as a "threshold"? 
These are questions that are worthy of further exploration, and as Batchelor repeatedly underlines, the research questions in a study will largely define the selection and place of paratexts in it.

\section{References}

Deane-Cox, Sharon (2014). Retranslation: Translation, Literature and Reinterpretation. London, Bloomsbury.

Genette, Gérard (1997a). Palimpsests. Literature in the Second Degree. Tr. Channa Newman and Claude Doubinsky. Lincoln/London, University of Nebraska Press.

Genette, Gérard (1997b). Paratexts. Thresholds of Interpretation. Tr. Jane E. Lewin. Cambridge, Cambridge University Press.

Hermans, Theo (1996). "The Translator's Voice in Translated Narrative." Target, 8, 1, p. 23-48.

Kovala, Urpo (1996). “Translations, Paratextual Mediation, and Ideological Closure.” Target, 8, 1, p. 119-147.

Tahir-Gürçağlar, S, ehnaz (2002). "What Texts Don't Tell: The Uses of Paratexts in Translation Research." In T. Hermans, ed. Crosscultural Transgressions. Research Models in Translation Studies 2: Historical and Ideological Issues. Manchester, St Jerome Publishing, p. 44-60.

\section{Şehnaz Tahir GürçaĞlar York University, Glendon College}

$* * * * * * * * * *$

Fruela Fernández and Jonathan Evans, eds. The Routledge Handbook of Translation and Politics. London/New York, Routledge, 2018, 524 p.

With the rise of research on translation and politics in Translation Studies, the time is ripe for a handbook on the subject. This is exactly what The Routledge Handbook of Translation and Politics provides, that is, an overview of the key ideas in and tendencies of translation and politics worldwide. The 33 chapters that comprise the handbook are written by leading scholars who have been chosen for their expertise and knowledge in the field (for instance, Eric Cheyfitz on translation and colonialism, Reine Meylaerts on translation in multilingual states, and Christina Schäffner on institutional translation). The handbook is co-edited by Fruela Fernández and Jonathan Evans. Fernández is a lecturer in Spanish translation at Newcastle University (UK), and his past work deals with the political impact of translation and the role of translation in contemporary politics $(2014,2017)$, whereas 